\title{
УДК 551
}

DOI: $10.23671 /$ VNC.2016.3.20835

\section{АРХЕОСЕЙСМОЛОГИЧЕСКИЕ ИССЛЕДОВАНИЯ В ДРЕВНЕМ ГОРОДЕ ХЕРСОНЕСЕ (СЕВАСТОПОЛЬ, КРЫМ)}

\author{
() 2016 В.В. Хапаев ${ }^{1}$, к.и.н., А.М. Корженков², д.г.-м.н., А.Н. Овсюченкоㄹ, \\ К.Г.-м.н., А.С. Ларьков ${ }^{2}$, А.В. Мараханов² \\ 1 Филиал Московского государственного университета имени М.В. Ломоносова \\ в г. Севастополе, Россия, 299001, г. Севастополь, ул. Героев Севастополя, 7, \\ e-mail: khapaev007@mail.ru; \\ ${ }^{2}$ Институт фризики Земли РАН им. О.Ю. Шмидта, Россия, 123995, г. Москва, ул. \\ Б. Грузинская, 10, стр. 1, e-mail: ovs@ifz.ru
}

\begin{abstract}
Руины хорошо изученного древнего города Херсонес Таврический дают уникальную возможность для восстановления сейсмической истории Южного Крыма за последние 2,5 тыс. лет. Специфические десормации в стенах Херсонеса Таврического однозначно свидетельствуют о неоднократных сильных землетрясениях, происходивших в далёком прошлом. В результате проведённых исследований удалось выявить следы, по крайней мере, двух или трех сильных землетрясений. Массовые разрушения в городе и его округе, не связанные с военными действиями, датируются: III в. н.э., V или VI в. н.э. и рубежом X XI вв. н.э. Совместное использование исторических и археологических свидетельств открывает принципиально новые возможности для оценки сейсмической опасности.
\end{abstract}

Ключевые слова: Херсонес Таврический, Севастополь, оценка сейсмической опасности, историческая сейсмология, археосейсмология, активные разломы.

\section{Введение}

Инструментальные сейсмологические наблюдения в Крыму начались сразу после разрушительных Ялтинских землетрясений 1927 г. Но период инструментальных наблюдений слишком краток для выявления всех сейсмогенерирующих структур, т. к. повторяемость сильных землетрясений может составлять несколько сотен, а то и тысяч лет. Согласно современным сейсмологическим представлениям, сейсмическая опасность определяется вероятностью достижения некоторого уровня сейсмических воздействий на данной территории в течение заданного периода повторяемости. В то же время, в сейсмологических каталогах инструментального периода наблюдений для всего Крымского региона имеется лишь одно сильное землетрясение - Ялтинское 1927 г., что сильно затрудняет возможности вероятностного подхода к оценке сейсмической опасности. Выход из этой ситуации возможен лишь с привлечением сведений о землетрясениях более далёкого прошлого.

Главная особенность сейсмотектоники Крымского региона, выявленная за период инструментальных наблюдений, заключается в расположении подавляющего большинства эпицентров в акватории Черного моря, где они недоступны для непосредственных наблюдений. В таких случаях, при оценке сейсмической опасности урбанизированных территорий, всё больше стали использоваться методы исторической сейсмологии и археосейсмологии.

Уникальную возможность для восстановления сейсмической истории Крыма за последние 2,5 тыс. лет предоставляет древний город Херсонес Таврический. Он 
является наиболее полно исследованным археологическим памятником Северного Причерноморья: раскопанная площадь превышает 12 га, хотя 2/3 городища остаются до сих пор неисследованными, что открывает возможности для дальнейшего совместного изучения как открытых, так и еще неисследованных памятников археологами и сейсмогеологами. Учитывая вышеизложенное, в 2015 г. группа сотрудников ИФЗ РАН провела рекогносцировочные археосейсмологические исследования в Херсонесе с участием научных сотрудников Государственного историко-археологического музея-заповедника «Херсонес Таврический» С.Г. Рыжова и В.Г. Самойленко, которая позволила сделать некоторые предварительные выводы.

\section{Методы исследований}

Помимо палеосейсмологических, в настоящее время продолжают активно развиваться методы археосейсмологии и исторической сейсмологии, направленные на выявление и параметризацию сейсмических событий путём анализа архитектурных и литературных памятников древности. Повреждения, наблюдаемые в древних руинах, могут быть вызваны плохой строительной технологией, выветриванием с течением времени (статическое повреждение), разрушением вражескими армиями, или результатом землетрясений. Распознавание сейсмической природы повреждений архитектурных памятников наиболее достоверно при выявлении преимущественно ориентированного обрушения и деформирования строительных элементов. Систематические наклоны, выдвижения, обрушения, повороты элементов древних строительных конструкций, характерные для стен определенных простираний, представляют собой кинематические индикаторы характера деформаций. Их использование даёт нам в руки эффективный количественный инструмент для решения главных задач археосейсмологической науки: а) выявления генезиса деформаций археологических памятников; б) оценки местной интенсивности сейсмических колебаний; в) локализации эпицентров методом, независимым от сейсмической сети и дополняющим её; г) идентификации зон с сейсмически наведенной деформацией сжатия и растяжения и д) продлении сейсмической летописи на временной интервал в сотни и тысячи лет [Korzhenkov, Mazor, 1999; Корженков, Мазор, 2001 и др.].

\section{Очерк истории Херсонеса}

Херсонес Таврический - античный и средневековый город в Юго-Западном Крыму, на территории современного Севастополя. Согласно новейшим исследованиям, он был основан около 528 г. до н.э. Версия немецкого ученого XIX в. Г. Шнайдервирта об основании Херсонеса около 422 г. до н.э. опровергнута в ходе археологических исследований, во время которых были найдены греческие амфоры, столовая посуда и глиняные черепки с процарапанными на них надписями (остраконами), датируемые последней четвертью VI-началом V вв. до н.э. Херсонес непрерывно существовал около 2000 лет: последнее тотальное разрушение города произошло в конце XIII в. в результате военного захвата, который не удалось пока точно датировать и связать с конкретным историческим событием. B XIV-XV вв. на руинах Херсонеса существовал портопункт генуэзцев и (во второй четверти XV в.) небольшое укрепление, принадлежавшее греческому княжеству Феодоро.

Херсонес неоднократно подвергался массированным разрушениям, но ни одно из них, за исключением разгрома конца XIII в., не связано с военными действиями: об этом свидетельствуют и письменные источники, и данные археологии. Город 
впервые был захвачен неприятельским войском в 988 г. в результате Корсунского похода князя Владимира. Однако это не привело к разрушениям, так как город был взят киевским князем на измор. Впоследствии русское войско длительное время пребывало в городе, там же состоялись торжественные церемонии крещения князя и его дружины, а затем - венчания князя Владимира и византийской принцессы Анны. Церкви и дворцовые здания, в которых проводились эти церемонии, по данным древнерусских летописей, сохранялись потом как минимум до конца XIII в.

Но, несмотря на неприступность херсонесских стен для внешних захватчиков, и они сами, и здания внутри города, в том числе монументальные храмовые сооружения, неоднократно разрушались, что приводило к восстановлению и усилению оборонительных стен и башен с применением иных строительных технологий, перепланировке и изменению функционального назначения городских кварталов, изменению технологий жилищного строительства. По данным археологических раскопок, проводимых в Херсонесе (с перерывами) с 1827 года, массовые разрушения в городе и его округе, не связанные с военными действиями, датируются: III в. н.э., V или VI в. н.э. и рубежом X-XI вв. н.э. С конца 80-х гг. XX в. в научной литературе ведется интенсивная дискуссия о причинах этих разрушений. Поскольку их не удается соотнести с военными действиями, большинство историков и археологов считают, что причиной этих разрушений могли быть землетрясения большой силы. Уязвимым местом такой трактовки является отсутствие упоминаний об этих сейсмических событиях в древних и средневековых письменных источниках [Хапаев, 2008].

\section{Региональная сейсмотектоника}

Систематические сведения о землетрясениях Крыма появляются с середины XIX в., а во второй половине XX в. начинают проводиться палеосейсмологические исследования. Они были систематизированы с выделением в районе Севастополя трёх основных сейсмогенерирующих структур [Никонов, 2000]. Несомненна сейсмогенерирующая роль Южно-Крымской (Прикрымской) складчато-надвиговой зоны, которая протягивается в акватории Черного моря вдоль Южного берега Крыма. В 1927 г. в Южно-Крымской зоне произошли Ялтинские землетрясения с М = 6,0 и $\mathrm{M}=6,8$.

Вдоль западного берега Крыма выделяется субмеридиональная Западно-Крымская зона. Она предположительно представляет собой крупнейший сдвиг, строение которого изучено слабо, преимущественно геофизическими методами [Вольвовский и др., 1992]. В этой зоне землетрясения средней силы происходили в 1875 $(\mathrm{M}=5,2)$ и 1957 гг. $(\mathrm{M}=5,5)$.

По косвенным данным о глубинном строении и распределении сейсмогравитационных образований выделяется Северо-Крымская зона, где под платформенными слабодислоцированными отложениями верхнего мела - кайнозоя трассируется глубинный разлом, разделяющий Скифскую плиту и альпийское сооружение Горного Крыма [Юдин, 2011]. Вдоль упомянутого глубинного разлома вытянута широкая полоса сейсмогенных обвалов и гигантских оползней [Борисенко и др., 1999]. Они приурочены к высоким обрывам прочных пород куэстовой моноклинали Горного Крыма и обусловлены благоприятными геоморфологическими и литологическими условиями. Сейсмотектонические разрывы голоценового возраста в этой полосе не выявлены. 
В районе Севастополя, где изучен Инкерманский активный разлом, выделяется субширотный отрезок Северо-Крымской сейсмогенерирующей зоны (рис. 1). Инкерманский сбросо-сдвиг лишь частично трассируется на суше, на восточной окраине Инкермана. Здесь были обнаружены выразительные палеосейсмодислокации гравитационно-сейсмотектонического типа [Борисенко и др. 1995]. Западнее Инкермана, разлом выделяется в Севастопольской бухте по данным бурения и интерпретируется как правый сдвиг [Иванов, 2014]. Берега бухты резко различаются. Если вдоль северного берега крупные боковые бухты отсутствуют, то на южном берегу расположены многочисленные затопленные долины балок, создающие типичный облик риасового побережья, не характерный для других берегов Крыма. Затопление балок указывает на локальное опускание южного берега залива, в отличие от более приподнятого северного. По всей видимости, нарушения в районе Инкермана расположены на восточном окончании сейсмогенерирующей структуры, скрытой под водами Севастопольской бухты.

Даже краткий обзор сейсмотектоники региона показывает возможность сильных землетрясений в районе Севастополя. Согласно имеющимся данным, потенци-

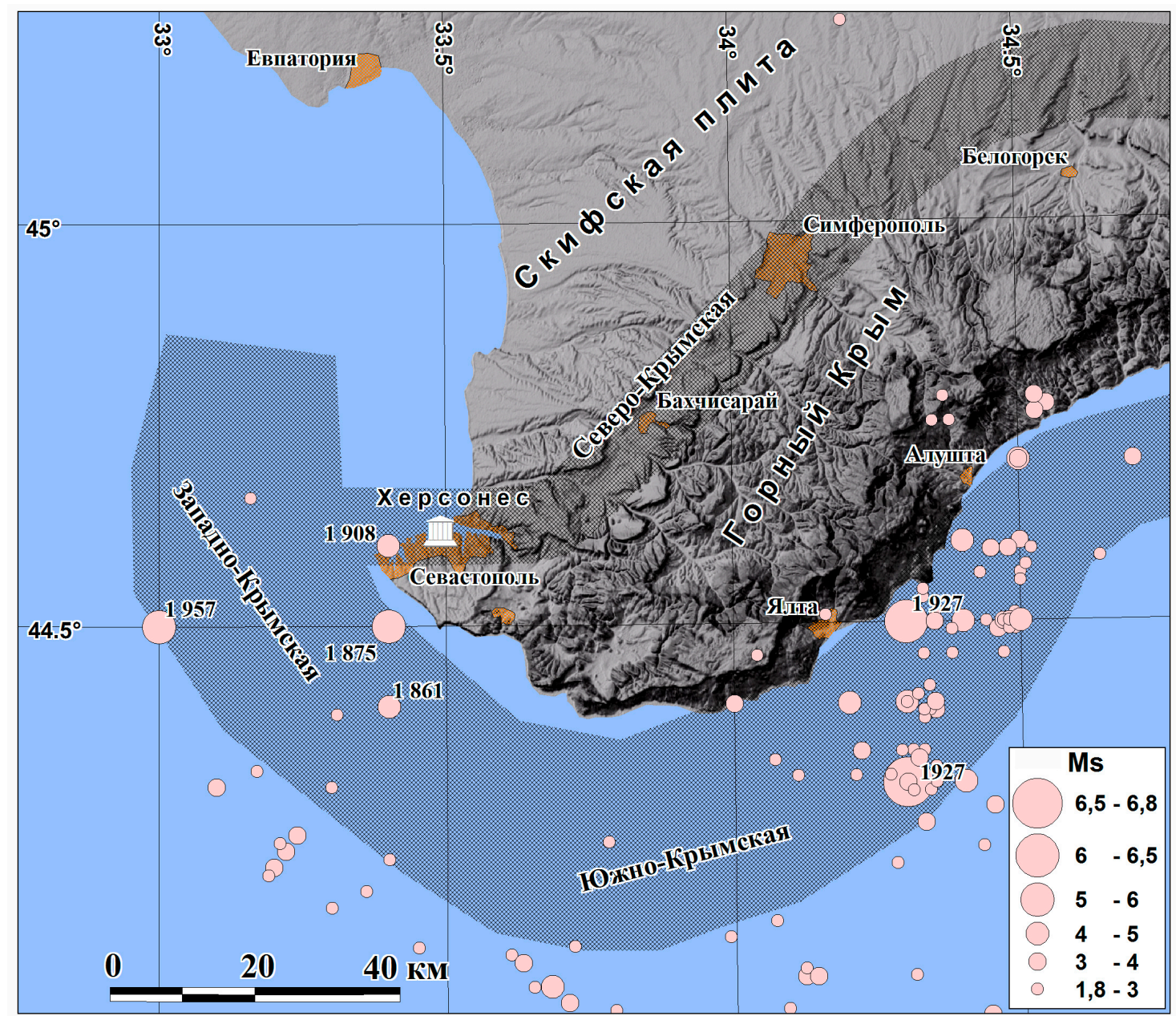

Рис. 1. Сейсмогенерирующие зоньл (заштрихованнье области) района г. Севастополь по инструментальным, археосейсмологическим и палеосейсмологическим данным. Кружками показаны эпицентры землетрясений по инструментальным и макросейсмическим данным за период 1800-2014 г2. [Пустовитенко и др., 1989; Shebalin, Leydecker, 1997; ГС РАН], с указанием года для сильнейших событий. 
альные очаги землетрясений расположены на разном удалении от города, вплоть до непосредственной близости.

\section{Результаты археосейсмологических исследований}

В руинах трех наиболее исследованных районов Херсонеса (Юго-восточного, Северо-восточного и Северного) нами был выявлен целый комплекс повреждений и разрушений, который включает:

- выкалывание и выдвижение целых фрагментов стен по ряду сопряженных сколовых трещин (рис. 2).

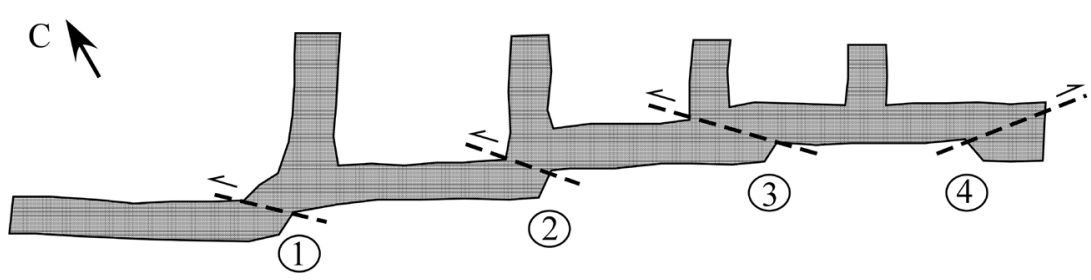

Двор усадьбы

a)
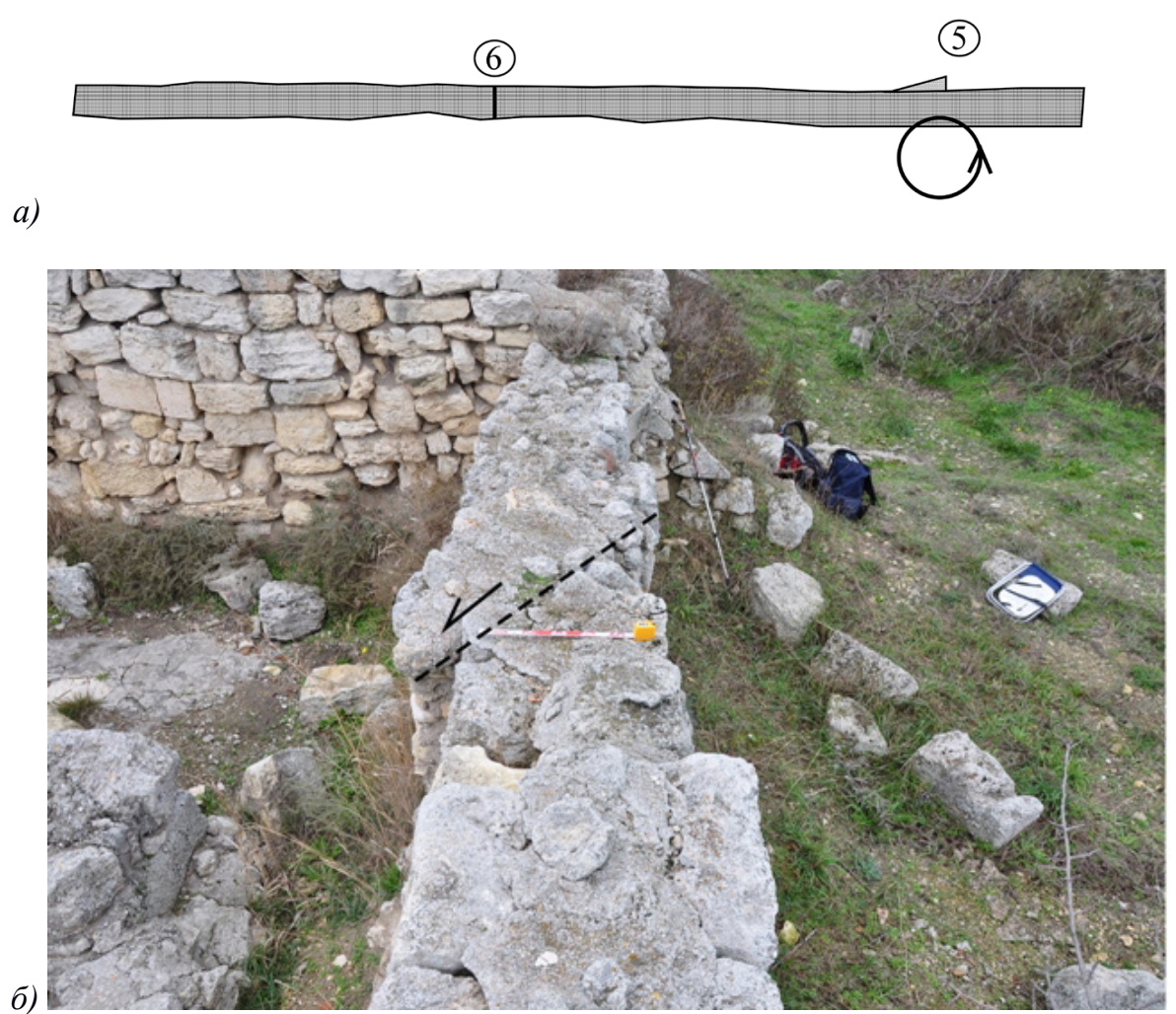

Рис. 2. Деформации стен внутреннего фасада усадьбы ХІ-ХІІІ вв. в VI квартале Херсонеса

(Северо-восточный район города, к северо-западу от главной улицы). (а) схематический план части двора усадьбы XI-XIII вв. в VI квартале с нанесенными на него образиами деформаџии; иифры в кружсчках: 1-4-выкалывания и выдвижения стен к ССВ, 5- поворот нижней части стены против часовой стрелки на $12^{\circ}, 6$ - сквозная трещина, пробивающая два крупных античных блока вторичного использования подряд. (б) Вид на одну из сколовых трещиин сверху. Простирание трещины - $175^{\circ}$, общее простирание расколотой стены - $120^{\circ}$, простирание обоих фрагментов стен близ скола - $126^{\circ}$, смещение по сколу - до 30 см. Снято с юго-востока. 
- развороты стен целиком, их фрагментов и отдельных каменных блоков вокруг вертикальной оси по и против часовой стрелки (рис. 3).

- изломы бутовых бесфундаментных стен XIII в. в связи с толканием их смежными перпендикулярными стенами (рис. 4). Подобные деформации уже наблюдались и описывались нами в стенах древнего города Мамшит в Израиле [Korzhenkov, Mazor, 2003].

- сквозные трещины (joints), пробивающие несколько строительных блоков подряд (рис. 5). Важно отметить, что в древнейшей части башни Зенона (ее так называемом ядре), построенной в III в. до н.э., сквозные трещины распространены не равномерно по всей окружности башни, но сосредоточены в ее частях с простиранием $20-35^{\circ}$ и $155-165^{\circ}$, что указывает (скорее всего) на сейсмогенный характер их возникновения. Всего нам удалось выявить и замерить 12 сквозных трещин в башне.
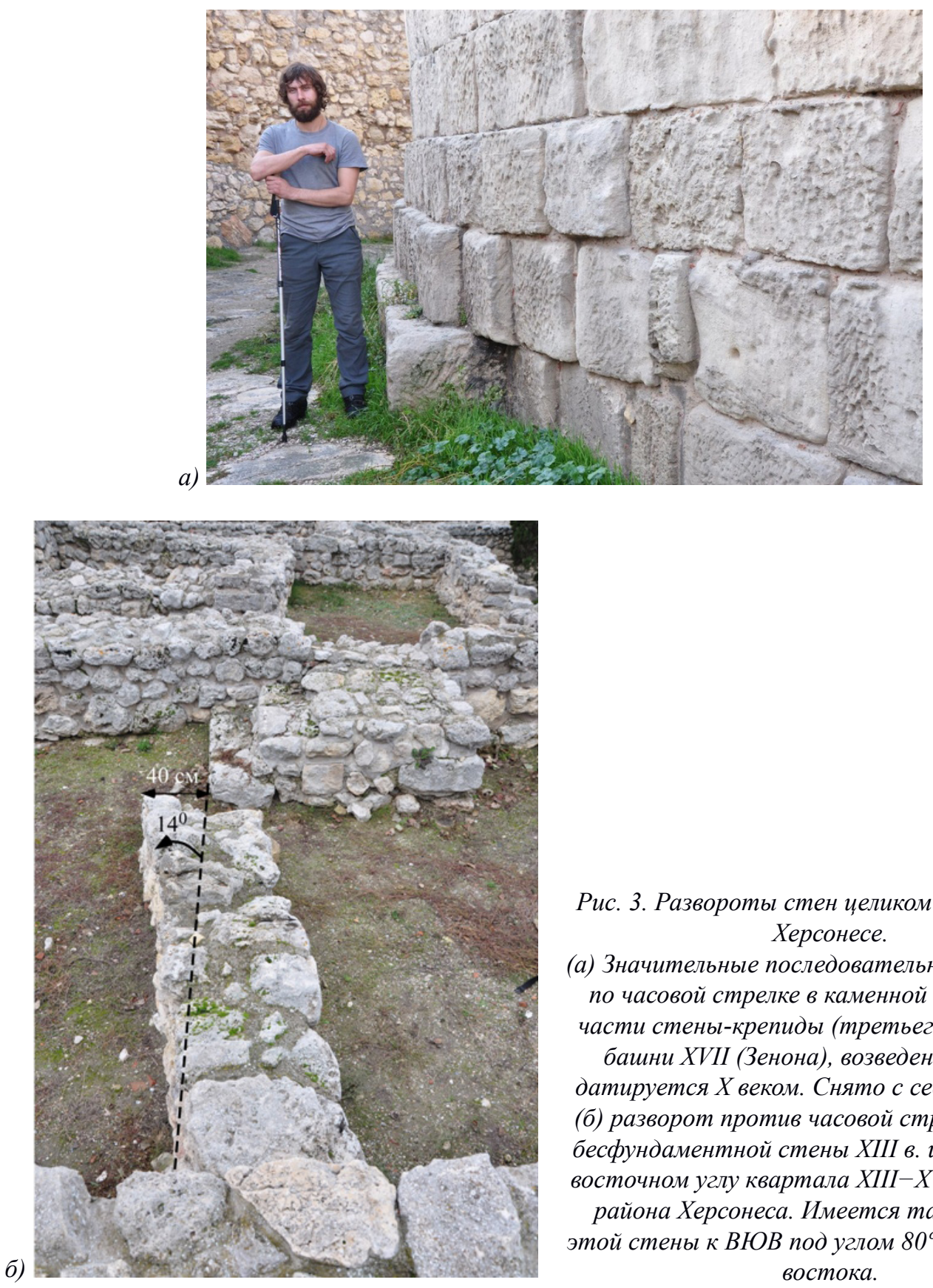

Рис. 3. Развороты стен целиком и их частей в Херсонесе.

(а) Значительные последовательныле развороты по часовой стрелке в каменной кладке в ЮВ части стены-крепиды (третьего утолщения) башни XVII (Зенона), возведение которой датируется Х веком. Снято с северо-востока. (б) разворот против часовой стрелки бутовой бесфундаментной стены ХІІІ в. иеликом в юговосточном углу квартала ХIII-ХVIII Северного района Херсонеса. Имеется также наклон этой стены к ВЮВ под углом $80^{\circ}$. Снято с юговостока. 


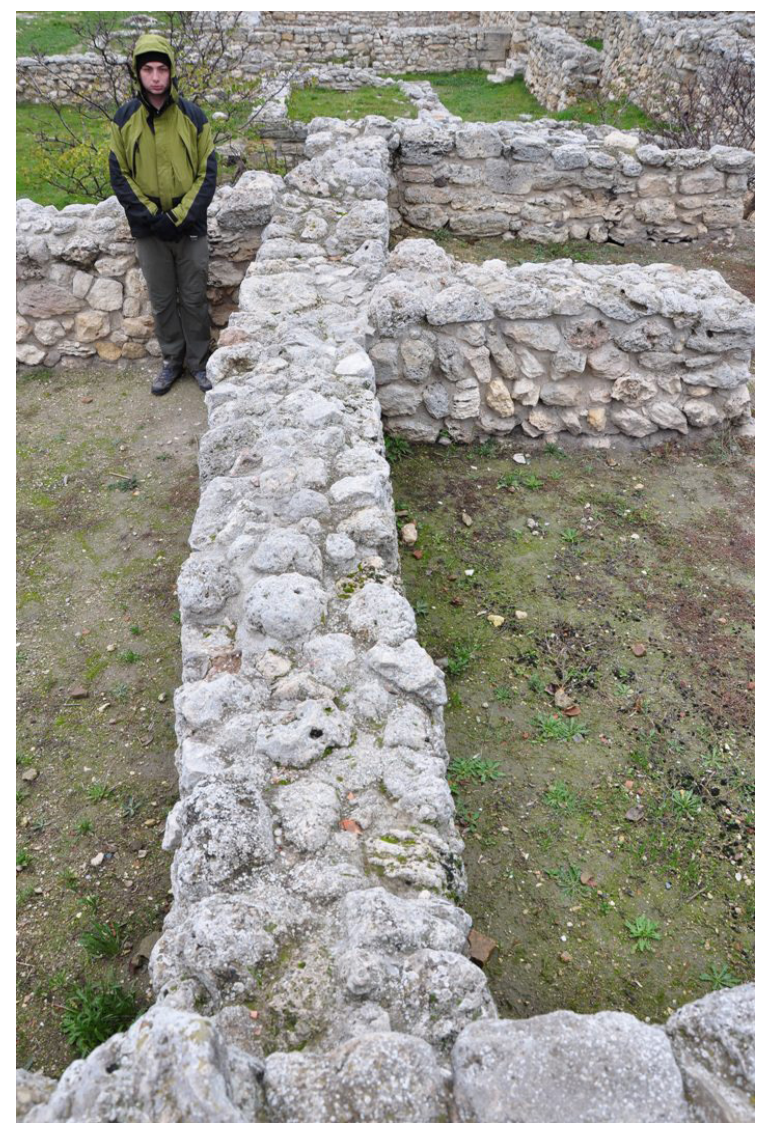

Рис. 4. Толкание стеной с простиранием $35^{\circ}$ противоположной стены, в связи с чем наблюдается излом последней с выпуклостью $\kappa$ ЮЗ. Имеется также наклон изломанной стены (с общим простиранием 130 ) к ЮЗ под углом $85^{\circ}$. Квартал ХІІІ-ХVIII. Снято с юго-востока.

Рис. 5. Сквозная трещина в башне Зенона, пробивающая два каменных блока подряд.

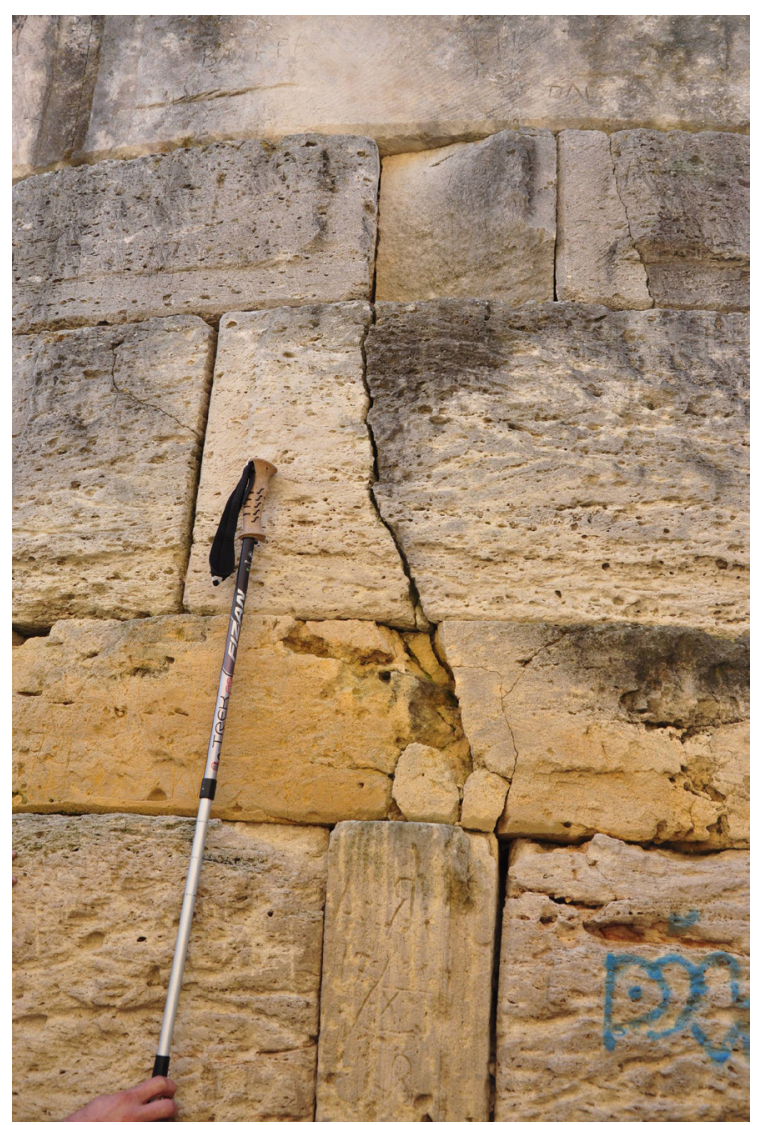



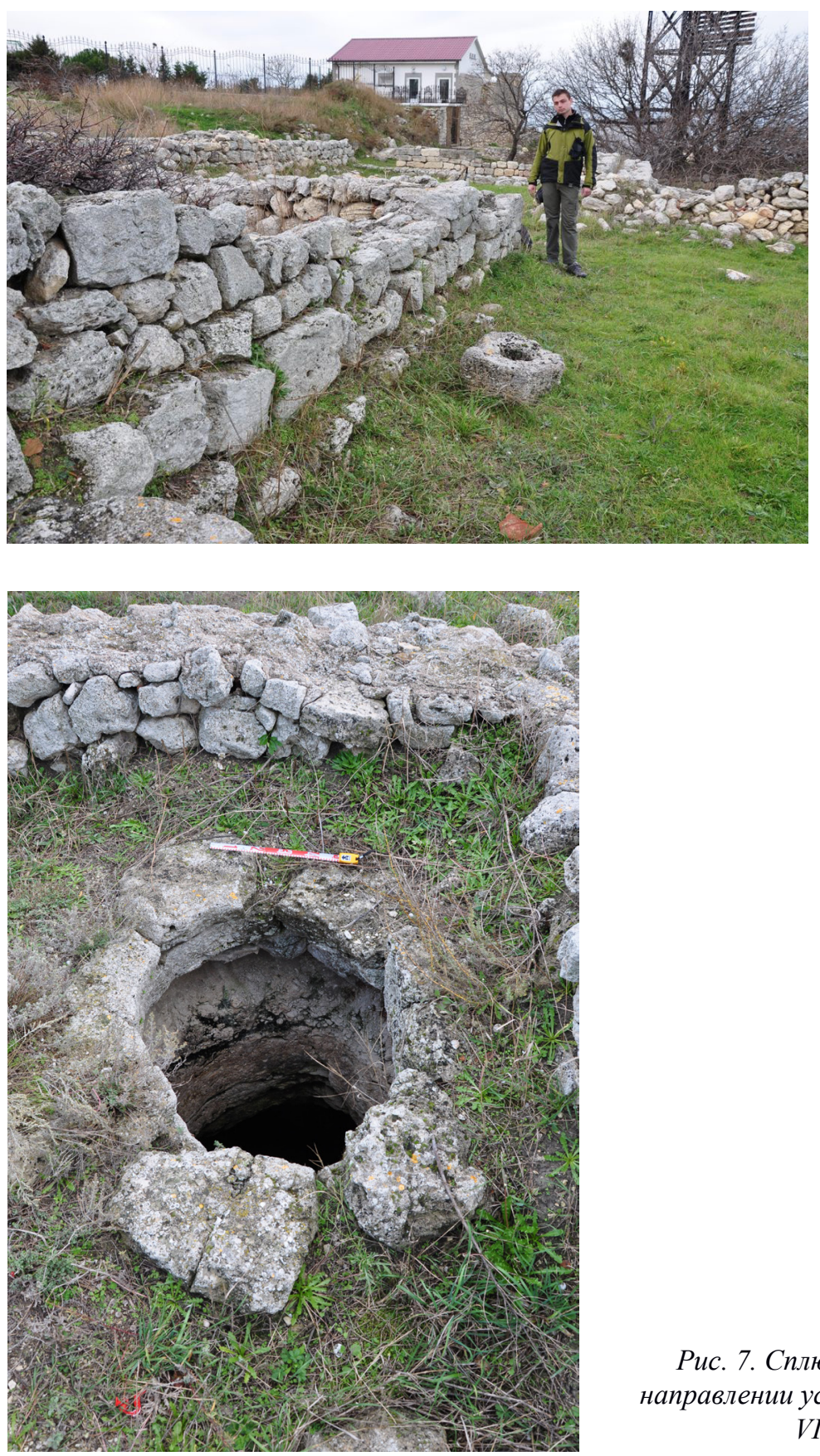

Рис. 6. Послойное и последовательное выдвижение рядов каменной кладки на ЮЮЗ в стене с общим простиранием $124^{\circ}$. VI квартал. Снято с юго-востока.
Рис. 7. Сплюснутое в субмеридиональном направлении устье каменного обклада колодия. VI квартал Херсонеса.

- послойные выдвижения и наклоны стен (рис. 6).

- деформации каменных обкладов устьев колодцев. В VI квартале нами было выявлено овальное удлинение устья одного из колодцев (рис. 7). Ясно, что изначально оно строилось округлым, но в настоящее время оказалось сплюснутым по оси $10^{\circ}$. Само по себе небольшое сплюскивание, возможно, и не привлекло бы нашего внимания, но оно было выявлено в квартале, где мы обнаружили 7 сколов в стенах Ю3 простирания, что согласуется с диаграммой существовавших тектонических (сейсмических) напряжений. Ко всему прочему, каменный обклад был разбит трещинами, одна их которых прошла насквозь через два каменных блока. 


\section{Заключение}

Описанные выше деформации в стенах Херсонеса Таврического однозначно свидетельствуют о сейсмогенной причине их возникновения. Нам удалось выявить следы, по крайней мере, двух или трех сильных землетрясений: одно - в стенах средневековых кладок XI-XIII вв., а два других - в разновременных стенах башни XVII (Зенона). Свидетельством первого античного землетрясения являются многочисленные сквозные трещины в каменной кладке ядра башни. Именно поэтому, по-видимому, пришлось возвести стену-крепиду вокруг башни в III в. н.э., затем еще одну, в конце V в. н.э. и, наконец, третью - в X в. н.э., в результате чего диаметр башни увеличился с первоначальных 8 до 22 метров, а первый пояс утолщения III в. н.э. был разобран, и в освободившемся кольцевом пространстве между ядром башни и утолщением V в. н.э. устроено караульное помещение. Второе землетрясение, следы которого обнаружены во внешнем поясе утолщения башни XVII, произошло после его строительства, т. е. после X в. Возможно, это было то же сейсмическое событие, которое повредило бутовые стены городских кварталов XI-XIII вв. Возможно также, что это - след более раннего землетрясения ХІ в., в ходе которого был разрушен практически весь город, в том числе обширные участки оборонительных стен, и особенно пострадали жилые кварталы [Хапаев, 2010].

По данным письменных источников и археологии, после XIII в. руины Херсонеса испытали разрушительное воздействие землетрясений XV в. (около 1423 г.) и 11 сентября 1927 г. Во время первого из упомянутых событий Херсонес находился в руинах, во время второго часть исследованных нами объектов была уже раскопана и находилась на дневной поверхности (башня XVII, квартал VI), часть еще находилась в земле (квартал XIII-XVIII).

Более точный возраст сейсмических событий, а также направления прихода максимальных сейсмических колебаний нам предстоит определить позже, в результате детальных исследований совместно с археологами. Местная интенсивность сейсмических колебаний была, по всей вероятности, не менее чем (VIII) $\leq$ Io $\leq$ IX баллов по Шкале MSK.

\section{Благодарности}

Работа выполнена при поддержке РФФИ (грант № 15-05-06197).

\section{Литература}

1. Борисенко Л.С., Никонов А.А., Останин А.М., Пустовойтов К.Е., Сергеев А.П. Сейсмодислокации в юго-западном Крыму (район г. Севастополя) // Доклады АН. - 1995. - Т. 343. №6. - С. 791-794.

2. Борисенко Л.С., Пустовитенко Б.Г., Дублянский В.Н., Вахрушев Б.А., Клюкин А.А., Ена А.В., Китин М.А. Сейсмодислокации и палеосейсмичность Крыма // Сейсмологический бюллетень Украины за 1997 год. - Симферополь: Изд.-во ИГ НАНУ, 1999. - С. 101-132.

3. Вольвовский Б. С, Соллогуб В.Б., Финетти И. и др. Строение и эволюция земной коры Черного моря. - М.: Наука, 1992. - 88 с.

4. Иванов В.Е. Об особенностях осадконакопления в устьях рек Юго-Западного Крыма в позднем плейстоцене и голоцене // Геология и полезные ископаемые Мирового океана. - 2014. - № 1. - С. 94-107. 
5. Корженков А.М., Мазор Э. Структурная реконструкция сейсмических событий: руины древних городов как окаменевшие сейсмографы // Изв. МОН РК, НАН РК. Серия общественных наук. - 2001. - № 1. - С. 108-125.

6. Никонов А.А. Сейсмический потенциал Крымского региона: Сравнение региональных карт и параметров выявленных событий // Физика Земли. 2000. № 7. С. 53-62.

7. Пустовитенко Б.Г., Кульчицкий В.Е., Горячун А.В. Землетрясения КрымскоЧерноморского региона. - Киев: Наукова думка, 1989. - 190 с.

8. Хапаев В.В. Письменные источники по истории Крымских землетрясений античного и средневекового периодов // Ученые записки Таврического национального университета. Серия «История». - 2008. - Т. 21 (60). № 1. - С. 3-8.

9. Хапаев В.В. Византийский Херсон во второй половине X - первой половине XI веков: проблема разрушения города // Дис. ... кандидата исторических наук. Севастополь. 2010. - 409 с.

10. Юдин В.В. Геодинамика Крыма. - Симферополь: ДИАЙПИ, 2011. - 336 с.

11. Korzhenkov A.M., Mazor E. Structural reconstruction of seismic events: Ruins of ancient buildings as fossil seismographs // Science and New Technologies. 1999. No. 1. - P. 62-74.

12. Korzhenkov A.M., Mazor E. Archeoseismology in Mamshit (southern Israel): Cracking a millennia code of earthquakes preserved in ancient ruins // Archeologischer Anzeiger. 2003, No. 2. - P. 51-82.

13. Shebalin N. V., Leydecker G. Earthquake Catalogue for the Former Soviet Union and Borders up to 1988. European Commission, Report No. EUR 17245 EN, Nuclear Science and Technology Series. ISSN 1018-5593 - Office for Official Publications of the European Communities, Luxembourg, 1997. - 135 p.

DOI: $10.23671 /$ VNC.2016.3.20835

\title{
ARCHEOSEISMOLOGICAL STUDY AT ANCIENT TAURIC CHERSONESOS (SEVASTOPOL, CRIMEA)
}

\author{
() 2016 V.V. Khapaev1, Sc. Candidate (Hist.), A.M. Korzhenkov², Sc. \\ Doctor (Geol.), A.N. Ovsyuchenko², Sc. Candidate (Geol.), A.S. Larkov², \\ A.V. Marahanov ${ }^{2}$
}

${ }^{1}$ Sevastopol MSU campus, Russia, 299001, Sevastopol, Geroev Sevastopolya str., 7, e-mail: khapaev007@ mail.ru;

${ }^{2}$ Schmidt Institute of Physics of the Earth of the Russian Academy of Sciences, Russia, 123995, Moscow, Bolshaya Gruzinskaya str., 10-1, e-mail: ovs@ifz.ru

Ruins of well studied ancient Tauric Chersonesos give unique possibility for restoration of Southern Crimea seismic history for last 2,5 thousand years. Specific deformations within the walls of Chersonesos clearly testify to the numerous strong earthquakes occurring far back in the past. As a result of the studies it was possible to reveal traces, at least, two or three strong earthquakes. Mass destructions in a city and its district, not connected with military operations, are dated: III century AD, V or VI century AD and a boundary X-XI centuries AD. Sharing of historical and archaeological data opens essentially new possibilities for seismic hazard assessment.

Keywords: Tauric Chersonesos, Sevastopol, seismic hazard assessment, historical seismology, archeoseismology, active faults. 